\title{
Editorial
}

\section{Nonprofit Governance, Organizational Purposiveness and Design}

\section{Antonin Wagner}

School of International Affairs, Management and Urban Policy, The New School for Public Engagement, 72 Fifth Avenue, New York, NY 10011, USA; E-Mail: wagnera@newschool.edu Academic Editor: Joe Roberts

Received: 29 September 2015 / Accepted: 30 September 2015 / Published: 16 October 2015

\section{Introduction}

The final article published in this Special Issue on nonprofit governance provides a platform for myself as the guest editor in two ways: both to reflect in a Postscript on the editorial process in which I became involved since posting a call for papers, as well as to write this Foreword that helps readers to become engaged in a meaningful discourse with the contributing authors. Incongruous as it may appear to be, I begin with the Postscript, as the Introductory Note to the Special Issue is not meant to integrate the articles published into a consistent concluding argument, but rather to evaluate my role ex post and at the same time to reveal to readers ex ante the premises based on which as guest-editor I selected articles for this Special Issue on nonprofit governance.

Serendipitously at about the time that the Editorial Board of Administrative Sciences approached me with its project, I came across the most recent issue of Social Research [1], with which this well-respected international quarterly commemorates the eightieth year of its continuous publication. Since its founding in 1934 as the journal of The New School for Social Research — at the time also known as the University in Exile-Social Research has been concerned with the relationship between social theory and practice and, more simply, with the intersection between political/social issues and the academic enterprise. To mark its "eight decades of sustained and rigorous reflection" [2] (p. xxix), Social Research published in its commemorative issue writings composed by leading members of the émigré community of the 1930s and 1940s as well as a foreword to the first issue by Alvin Johnson, The New School's first president. In it, Johnson expresses the hope that Social Research will become a platform for cross-fertilization of cultures [3] (p. 3), drawing for the most part from among continental scholars abroad, while appealing to interests that transcend the boundaries of a single country. 
Johnson's Foreword to the first issue of Social Research, and especially his vision of research as a process "in which form and material share equally in creation" [3] (p. 4), resonated with me, when I began putting together the call for papers for this Special Issue. I always was - and still am — convinced that the topic of how to run organizations in general and nonprofits in particular represented the kind of material that is — as Johnson put it — of the world at large. I questioned, however, whether it makes sense to use this Special Issue to launch a process of cross-fertilization by actively seeking contributions from outside the United States, the country that for the last half of a century or so clearly has dominated the field of social studies commonly being referred to as third-sector research. Conversely, I was aware that the position of intellectual leadership, which American researchers and institutions assume in this field, has come with the price of a somewhat parochial operating definition of third-sector organizations that focuses on the US tax code. In order to initiate a creative process of research, in which method (form) and subject (material) share equally, I made two important strategic decisions when drafting the call for papers. For one, I defined that the term "nonprofit" used to describe the topic of the Special Issue ought to be understood in the wider sense to include a broad array of so-called intermediate organizations. The advantage of this broader definition lies in bringing together conceptually disparate parts of the collaborative system of actors that has emerged to advance societies in many parts of the world, by decentralizing government and pluralizing the state. Secondly, I decided to seek articles for publication that contribute either to knowledge deepening (by improving our understanding of how nonprofits are governed at the organizational level) or to knowledge widening (by advancing understanding of the role nonprofits play as intermediaries in society at large).

I hoped that by drafting the call for papers in this way, it would be possible to appeal to research interests that transcend the boundaries of a single country and attract a broader range of scholars, one that represents both the more mainstream strand of organization studies (including the practice-oriented discipline of management) and the New School's research tradition of social theory, understood as an exercise in critical reasoning and an intellectual quest for social justice. However, the idea behind my framing the call for papers accordingly was not to promote the latter approach at the expense of what traditionally has come to be referred to as third-sector research, but rather to advance knowledge by taking advantage of what I consider largely complementary methodological approaches. My emphasis on complementarity notwithstanding, I nevertheless admit that in my own work I exhibit a preference for the social-theory approach, to which I became exposed during the last 15 years when teaching at The New School. In this respect there is no denying that my exposure to social theory has influenced the approach I took as guest-editor to encouraging contributions for the Special Issue.

On the following pages I will use elements of the research tradition my university began building on in the 1930s to discuss the articles on nonprofit governance that were published in the Special Issue. I begin with Martin Greller's text, which represents a nice example of critical reasoning and therefore lends itself to familiarize the reader with the methodological aspect of social theory.

\section{A Reflective Conversation on Organizational Purposiveness and Governance}

To contextualize Martin Greller's paper I first have to acquaint the readers with what I consider to be the foundations of critical reasoning, which for the first time were laid out in a systematic way by Immanuel Kant in the three volumes of his Critiques (Critique of Pure Reason (1781), Critique of Practical Reason (1788), Critique of Judgment (1790)). "Critical" for Kant meant that we cannot 
comprehend the world as it is, but only as it appears to the human mind and its intellectual capacities. For our purpose of understanding critical reasoning, the last volume is especially important, as Kant explains there that 'judgment' stands for the power or faculty of the mind for "thinking the particular under the universal" [4] (p. 103). According to Kant there are two specific ways for using the intellect to subsume a particular under the universal, one that is expressed in a 'determining' judgment, the other in a 'reflective' judgment. In a determining judgment we subsume particular events (such as the famous apple that fell from a tree on the head of Isaac Newton) under a universal (namely the law of gravity). Determining judgments are governed by the general principles of understanding, with which Kant deals in his Critique of Pure Reason. The more distinctive role assigned to the faculty of judgment in the third Critique is the reflective role, namely that of "finding the universal for a given particular" [4] (pp. 104-107). Through reflective judgment we ascribe ends or purposes to particular objects, thereby characterizing them as purposive or functional.

But what are these objects to which we assign through reflective judgments purposiveness and functionality? Surprisingly somehow, Kant deals in the first part of Critique of Judgment only with works of art and in the second part with nature as the two types of objects to which we assign - through reflective judgments - the quality of being purposive and functional. What he left out there from his consideration was the purposiveness of institutions (including organizations), which he considered as the other pillar, on which together with the works of art rest the culture human beings created on the 'great stage of the world', after they have passed from the state of nature to the state of civilization. But in Critique of Judgment Kant lays at least the foundation for the much larger undertaking of a fourth Critique, understood as a critical theory of institutions in general and organizations in particular, never fully executed except as sketches in a series of essays he wrote toward the end of his life. In Critique of Judgment, these foundations are incorporated in a few paragraphs Kant dedicates to organisms, which for him represent the prototype of purposive entities. As such, they cannot be fully comprehended through a nexus causalis (that is through the relationship between cause and effect), but must be regarded as constituted through a nexus finalis, that is in a teleological context and as a purposive system "in which everything is end and reciprocally a means as well" [4] (p. 546). Kant uses the metaphor of a growing tree to explain how such purposive systems function. In a growing tree one part, namely the leaves, are a cause of another part by nurturing the roots; yet the leaves depend on the roots as well, as they cannot exist without the minerals and water delivered by the roots. Furthermore, the tree as a whole is in a sense both an effect of its parts (as the tree cannot exist without its leaves and roots), as well as a cause of its parts (as leaves and roots function properly only as long as they are on the tree).

In itself, Kant's abstract methodological discourse about how to comprehend purposive systems in general and organisms in particular would not have attracted the attention of social theorists, were it not for the footnote he attached to the text ( $\$ 65)$, in which he dwells on the phenomenon of reciprocal causation that exists both between the parts as such as well as between the parts and the whole they constitute. In this footnote Kant draws an analogy between an organism (understood as an ideal type of purposive system) and the term "organization" that according to him is being used "in a recent complete transformation of a great people into a state" [4] (p. 545). As I have demonstrated elsewhere [5] (p. 241), it is safe to assume that the "great people", to whom Kant referred in 1790, are the United States. Only fourteen years before the philosopher wrote this footnote, a loose partnership of former American colonies had declared its independence from the British Crown and by 1787 had articulated in the 
Constitution what the struggling country might become: a body politic, in which-according to Kant"every member should surely be purpose as well as means, and, whilst all work together towards the possibility of the whole, each should be determined as regards place and function by means of the Idea of the whole" [4] (p. 545).

When reading Martin Greller's article, I got the impression that his text brings back to life Kant's idealistic view of political organization. As a matter of fact, through his narrative the author engages his readers in a reflective conversation [6,7] on purposiveness of organizations, not unlike the German philosopher did more than 200 years ago. Greller begins his conversation by ascribing specific purposes to two different types of organizations: Corporations have as a central part of what they are set up for the creation and distribution of financial surpluses, while nonprofits serve what he terms a societal purpose. Based on this distinction Greller then questions the proposition that one should look to for-profit corporations for guidance about how to conceptualize nonprofit governance, as is being done by the proponents of the principle-agent model in much of the current literature.

According to Greller, what lies at the core of understanding organizational governance is how to measure the performance with respect to the outcome organizations are expected to achieve. The central notion in agency theory is that manager-agents act on behalf of the owner-principals, who are the shareholders represented by the board. Their interests determine the definition and measurement of performance, and executive compensation serves to award the manager-agents for having achieved through the organization's activities the financial goals set by the owners. Nonprofits, however, belong to society at large, so that their boards are accountable to themselves and cannot pretend to govern the organization on behalf of anybody particular. Even if one thinks of nonprofits as being accountable either to important funders or to the clients they serve, it does not follow from such "substitute" principals that these actors should have a stake in deciding which measures should be used, when assessing a nonprofit's performance in achieving the societal outcomes it has been set up to produce.

Greller then continues building his argument by questioning whether it makes sense to frame the governance process of such a different type of organization as a principal-agent relationship. Originally practiced by landowners for whom overseers manage agricultural operations at a distance, the principalagent framework represents a relatively primitive conception of authority relations between master and servant. When applied to organizations in contemporary capitalist societies, the framework focuses - at least implicitly — on a situation, in which those who contribute financial capital (mostly shareholders, occasionally also the state) are viewed as the only authorities to which the organization is accountable. Greller suggests that for two reasons the alternative institutional framework of leasehold would be better suited than ownership-based agency theory for modeling governance in a nonprofit environment. Unlike the latter approach leasehold does not institutionalize top-down authority relations between shareholders (represented by the board) and management, nor does it privilege those who contribute financial capital above the many other parties who provide critical resources to achieve the organizational purpose. Furthermore, what matters in a leasehold perspective is that the alignment of interests between board/management and multiple providers of resources is grounded in a relational contract between the two sides, rather than in a transactional one, based on which principals use executive compensation to award managerial agents for fulfilling the owners' presumed (financial) agenda.

The fact that in a leasehold context relational contracts between equal parties replace transactional ones between target-setting authorities and their managerial executioners is crucial in a nonprofit 
environment. Here, the key strategy question is not how to govern organizations in view of achieving financial goals, but how to develop capacities for creating societal value relevant to a nonprofit's mission. The capacity to create this kind of value is not grounded in the internal relationship between the board (representing a principal who defines the desired organizational outcome) and management (as its willing executioner), but rather emerges from the external relationship board and management maintain with the organization's environment. Greller is therefore right to emphasize that a nonprofit's capacity to create societal value "is something to be nurtured and maintained" by senior leadership. Expanding Greller's argument somewhat, I would add the requirement that senior leadership treat employees and volunteers inside the organization with the same attitude of continuous nurturing with which they treat the organization's environment. Such an understanding of governance moves nonprofits into the sphere of purposive systems, for which Kant uses the metaphor of the growing tree (and Greller the one of ecological systems) and in which the whole in a sense is both an effect of its parts, and yet also a cause of its parts.

But the metaphor of a growing tree used by Kant to explain the principal of reciprocal causation and to understand the functioning of purposive systems poses a logical problem, as the human mind conceives of causes always as earlier than - or simultaneous with-but never as later than their effects [5]. Kant realized that the only way he could understand the functioning of purposive systems, in which the whole is not only posterior to its constitutive parts, but precedes them as an intention, is by employing in addition to the growing tree also the watchmaker as a second and complementary metaphor. It demonstrates that in the case of technical and artistic production - such as making a watch (or for that matter creating an organization) - the design of the whole is anterior to the parts, i.e., precedes in the mind of the watchmaker the production of the various parts. These parts, in return, are then used as means to an end, when the watchmaker, in a process of intelligent production, assembles them to a whole (which as an object is posterior to its constitutive parts).

\section{Designing Governance for Stakeholder Controlled Firms}

Unlike Kant, Greller did not address in his reflective conversation on organizational governance the logical problem that arises from comprehending organization as the prototypical purposive system, nor did I expect him to do so. Keith Taylor, however, deals in his paper with the issue of why it makes sense to conceive of the process through which organizations in general (and those assuming the function of societal intermediaries in particular) come into existence as a case of intelligent production by design. Originally used mostly in fashion, architecture and engineering, the idea of intelligent production by design has over the years been broadened and applied to other professions engaged in converting existing to preferred situations. Recently, one can observe a tendency to think also of professions dealing with organizations, other forms of institutions, and entire policies as design professions. Among the first to take a design approach to understanding how institutions work were the 2009 Economics Nobel Prize Laureate Elinor Ostrom and her husband Vincent. In 1973 the two researchers founded the Workshop in Political Theory and Policy Analysis at Indiana University. It then became the venue for their extensive research relating to common property institutions and the development of eight design principles, explaining how a community can govern their commons sustainably and equitably. These so called Ostrom Design Principles (ODPs) have since been modified and expanded to include a number 
of additional variables believed to affect the efficacy of co-operatives and other self-organized governance systems.

The modified Ostrom design approach to understanding effective self-governance of individuals within complex socio-technological systems represents the kind of intellectual tradition, based on which Taylor - a Research Associate with the Workshop in Political Theory and Policy Analysis at Indiana University - is building his argument. As indicated in the title of his contribution, the purpose of his paper is to draw a management lesson from the co-operative institutional model for how to achieve robustness of governance, a lesson that is applicable also to third-sector or nonprofit organizations (understood here in the wider sense as societal intermediaries). Taylor begins his argument by pointing out that, with their control mechanisms anchored predominantly in the board-management relationship, third-sector organizations are traditionally indebted to a "unitary" tradition of governance. Such a governance practice is diametrically opposed to a more "pluralist" governance structure realized in stakeholder-owned firms. Instead of focusing on top-down control mechanisms, such firms engage a broad stakeholder base that is expected to provide critical information and policy solutions to achieve a desired organizational outcome.

To promote such a template of self-governance in his contribution Taylor uses the ODPs as a diagnostic instrument for assessing governance robustness, specifically for locating potential governance vulnerabilities. To this intent he presents an archival case analysis of Choctaw Electric Co-operative (CEC), a stakeholder organization that recently was haunted by a ruptured governance structure. The rupture consisted in a perception by the membership of their exploitation by management, taking the form of an excessive CEO compensation package (annual wage and retirement annuity), seemingly financed at least in part by increased fuel costs charged to the member-ownership of the electric company. In his analysis Taylor focuses on observed patterns and processes of governance behavior that may indicate a stakeholder-governed firm has deviated from a pluralistic governance style to a unitary one. In this context he lists the ODPs that appear to have been violated by the CEC board and/or management. They include the lack of clear user boundaries between member and non-member users (exploitation of the member-owner community by charging members excessive electricity rates); incongruence of appropriation and provision rules (misalignment between benefits obtained and inputs provided by members); and deficient monitoring of common resources and services provided (lack of access to board meetings and minutes).

In concluding his paper, Taylor emphasizes a set of lessons that can be drawn from the co-operative institutional model for enhancing more pluralistic forms of governance practicable in the third sector. First he compares in more general terms the advantages/disadvantages of a unitary and a pluralist governance style. In this context he acknowledges that unitary (for-profit corporate) governance remains the best-developed governance template that influences theory, research, and practices across most of the organizational landscape, including the co-operative sector itself. He then argues that the ODP design approach to understanding governance illustrates the organizational vulnerabilities that emerge, when firms adopt a unitary governance style and stakeholders become separated from organizational control mechanisms. Conversely, he emphasizes the organizational robustness that results from adopting a pluralist view that promotes integrating stakeholders into governance processes.

In the second part of the conclusion Taylor focuses on accountability as a management issue, for which specific lessons can be drawn from an electric co-operative in particular and then applied to 
third-sector organizations in general. As a general rule he states that many nonprofits operate practically as memberless entities and are therefore under-prepared to engage stakeholders in the way organizations are being governed and made accountable to the constituency they serve. I am inclined to complement this theoretical argument by giving it a more practical twist, not least based on research carried out by the Ostrom Workshop about how stakeholder participation in electric cooperatives contributes to more effective service provision. There is some anecdotal evidence that in territories serviced by electric co-operatives, in which consumers are member-owners with governance rights, providers exhibit an enhanced ability of responding to a dynamic technology environment and changing consumer expectations, relative to territories serviced by investor-owned providers [8]. One can draw an interesting governance lesson from this observation that — with respect to their accountability — might also be applied to nonprofit service providers. In terms of consumer expectations and information technologies they are often exposed to changes in the environment similar to the ones observed in the energy sector. Unlike in the electric energy sector, neither members nor providers of financial resources (representing the equivalent of investors in the private sector) control nonprofits, so that as fiduciaries of the public at large their boards tend to act as if they were accountable merely to themselves for how to provide services in the most effective way possible [9].

Given his focus on stakeholder participation in co-operatives, it is understandable that Taylor did not deal in detail with the issue of how to enforce effective governance behavior of nonprofits, either by instituting legally binding forms of membership (representative governance) or by letting stakeholders participate in organizational decision-making (participatory governance) [9]. But the next paper to be discussed in this Introductory Note deals with exactly this issue of how to make nonprofits accountable to their constituencies for effective service provision, by establishing membership structures and encouraging organizational self-governance at the local level of society.

\section{Membership and Civic Engagement}

In their case study about asset transfer of public leisure facilities in England, Geoff Nichols and Associates explore the issue, to what extent devolving the provision of public services to voluntary and self-governing associations is more sensitive to local needs and therefore also more effective than provision by central (or even local) governments. In this respect their contribution to the Special Issue complements Taylor's analysis of how self-governance affects accountability of societal intermediaries in the U.S. electric energy sector, albeit from the perspective of a different geographic region and a different sector of service provision.

In the introduction to their case study, the authors point to the difference that exists between asset transfer from local governments to volunteers and outsourcing of public services provision to third sector organizations. The latter strategy is being applied in Great Britain (and elsewhere) predominantly when triggered by reductions in local government budgets, thus serving the economic purpose of compensating government and market failures or — as Nichols and Associates put it—of ["plugging] a provision gap that cannot be met effectively by the private or public sectors". Asset transfer, on the other hand, might be understood to represent a step towards associational democracy and in this respect is part of a political program to empower individual citizens and their communities. Reading their case study in the light of this distinction between decentralization of government (as the economic dimension of public service provision) and pluralization of the state (as the political dimension), helped me to better understand, why 
and how self-governance contributes to making societal intermediaries in general and nonprofits in particular more responsive to users' demands.

In the economic sphere of society nonprofit organizations traditionally have assumed the role of societal intermediation by compensating government and market failure. In many countries these organizations are considered as potential recipients of tax-exempt donations, under the condition that they do not cater to a particular constituency, but serve the public at large. As a proxy for obliging them to public service provision, nonprofit boards are usually prevented from having member-owners and from distributing financial surpluses to any persons associated with the organization, including employees. On the one hand, the construct of nonprofit ownership (i.e., the principle that boards represent fiduciaries of the public at large) is being used as a vehicle for creating a sense of trust towards organizations providing so-called "meritory" goods. On the other hand, this kind of fiduciary ownership implies that board members are accountable to nobody else but themselves. Such a paternalistic understanding of accountability prevents nonprofits from instituting forms of organizational self-governance by user-members. Should local governments believe that their citizens are educated enough to choose what matches best their preferences, they will provide vouchers as a means of user-centered financing of social services, rather than outsourcing them to nonprofit providers [9].

By contrast to the situation in the economic sphere of society, where nonprofits are incorporated as "memberless" quasi-public entities (and recipients of tax exempt donations), societal intermediaries assuming the political role of building democracy at the local level are often incorporated as associations with legally binding systems of representative governance. Their members have the right to elect the board of directors and are in a position to exercise the monitoring role that shareholders are expected to perform in for-profit corporations. Even in sectors of societies such as local leisure facilities-where representative governance is usually not the norm for organizations to perform the role of societal intermediaries - alternative mechanisms of self-governance are available for enforcing effective organizational behavior. As the case study under consideration here exemplifies in much detail, quite a promising approach to making board and management of societal intermediaries accountable, if not to the public at large at least to the core constituency served, consists in letting stakeholders participate in organizational decision-making.

Such a participatory governance style, which engages citizens as social activists in the provision of social services seems to have become a common practice in civic initiatives not only in the area of leisure facilities, but in many other fields of service provision in England and, of course, in many other parts of the world. As Nichols and Associates point out, the transfer of material and immaterial assets linked to such forms of organizational self-governance demonstrates that leasehold and not ownership would represent the appropriate institutional framework describing the way in which organizations outside the confines of the market and the state are being run. In their opinion leasehold functions as "a bridge between public ownership and volunteer governance" for the transfer of equipment and buildings necessary to provide specific services. In this respect, the case study being discussed here provides not only a valuable complement to Taylor's paper on designing robust self-governance, but also corroborates important insights to be gained from Greller's reflective conversation, in which he assigns to nonprofits the purpose of creating social (and I would like to add political) value. 


\section{Conclusions: Nonprofit Governance and the Quest for Social Justice}

In concluding my Introductory Note, I would like to assess what as the guest-editor I have and what I have not achieved by taking a social-theory approach in putting together the Special Issue on nonprofit governance. As I pointed out in the introductory section, social theory as defined by the New School's émigré community of the 1930 s represents an exercise in critical thinking that fuels a quest for social justice. Therefore, method and content, that is the formal and material aspect of social theory shall represent the standard against which I am going to evaluate what the articles published here have accomplished.

\subsection{Formal Aspect of Social Theory}

As I mentioned in the Introduction to this note, critical thinking for Kant meant that we cannot comprehend the world (including the world of institutions) as it is, but only as it appears to the human mind and its intellectual capacities. Economists have a tendency to consider institutions in general and organizations in particular either as constraints to "free choice" or-even worse- deal with them as mere means for the pursuit of individual satisfaction. Mimicking such an 'instrumentalist' approach, many management and business school academics are trying to transform organization studies into a branch of positive social sciences. They see the purpose of their intellectual endeavor in discovering deterministic laws and thereby replace "all notions of human intentionality with a firm belief in causal determinism" [10] (p. 77). Quite to the contrary, the three authors discussed here deviate in their texts from the instrumental conception of organizations that traditionally has been promoted by economic theory. Rather, they attempt to comprehend societal intermediaries in general and nonprofits in particular as being constituted through their specific purposiveness and as an outcome of human intentionality. Taylor, for instance, demonstrates in his paper that design principles matter and that applying them contributes to more robust self-governance of co-operatives. Likewise, Greller in his reflective conversation derives the alternative institutional framework of leasehold for understanding nonprofit governance by defining the specific purposiveness of nonprofits as one of creating social value for society and not financial value for shareholders. And as one citizen interviewed by Nichols and Associates in their case study explains, "[the transfer of assets] encourages individuals to take charge of their communities through philanthropy, civic participation and social enterprise".

\subsection{Material Aspect of Social Theory}

The proposition that societal intermediation in general and nonprofits in particular belong to the sphere of human intentionality and therefore ought to be dealt with in a teleological and not merely in an instrumental context, was thought to function as an incentive for management academics to become involved through their research in the quest for social justice or what represents the material aspect of social theory. In the footnote mentioned above, Kant provides a template for how one could argue that societal intermediaries/nonprofits_-viewed in a teleological perspective - are vehicles for achieving social justice. As I pointed out, Kant describes in this footnote America's body politic as a purposive system, in which "all (members) work together towards the possibility of the whole, (while) each member should be determined as regards place and function by means of the Idea of the whole" [4] 
(p. 545). The term "whole" in the statement refers to what Kant considered the primary association of citizens in their just state, an association that establishes a union of all members of society, a union that is "in itself an end which each of them ought (my italics) to have" [11] (p. 44). The term "members" points to the citizenry, but also to the secondary associations many citizens join for achieving jointly a goal, which they have [11] (p. 44). From this pluralistic structure of the public sphere, through which secondary associations are subordinated to the primary one, it can be deduced that societal intermediaries (including nonprofits) are held to the same standard of social justice as the State itself.

I was not surprised that of the three articles under discussion here, only the one authored by Greller deals (in rather general terms) with this issue of how societal intermediaries serve the ultimate goal of social justice, by attributing to nonprofits the specific purposiveness of "creating social value". The other two articles focus more specifically on the concrete missions the organizations under consideration have been set up to achieve, namely the distribution of electric energy in rural Oklahoma and the provision of leisure services in England. Such a treatment of social justice is not atypical for the current management literature, where the argument that nonprofit organizations (and other societal intermediaries) indeed play a role in creating a just society is being derived not from the teleological, but rather from the instrumental consideration originally promoted by the Internal Revenue Service (IRS) of the United States. In Article 501c3 of the USA Tax Code nonprofits are being granted tax-exempt status based on a list of specific missions that links them to public service provision, without any reference to the overarching goal of social justice. It seems that also in the articles published here, the instrumental focus on how intermediate organizations achieve specific goals has prevented the authors from dealing with governance in the teleological context of social justice.

But the purpose of my Introductory Note is not to exhibit what we failed to achieve by putting together this Special Issue, but rather to focus on how a better understanding of nonprofit governance could advance the human quest for social justice. One of the more important lessons I was able to draw from my preoccupation with Kant's Critique of Judgment is the appreciation I have of the importance of distinguishing between formal and material purposiveness of organizations. To explain the distinction, Kant [4] (§ 62) uses the geometric figure of the circle. Formally speaking (i.e., as an Idea), the purpose of the circle is to represent the line that connects all points positioned at equal distance from the center. In the course of evolution humans have learned how the insight into what constitutes the formal purposiveness of a geometric figure could be put to practical (that is material) use, for instance in the form of a wheel in the physical world to move objects from one place to another or in the shape of a round table in the political world, as an incentive for communities to finding commonly accepted solutions for particular problems.

One does not have to re-invent the wheel, in order to make nonprofit management a more relevant discipline that becomes engaged in the human quest for social justice. As the articles published in this Special Issue suggest, applying Kant's distinction between formal and material purposiveness to the study of nonprofit governance and complementing the instrumental approach with a teleological one could make a critical difference in rebooting on a more progressive track an academic enterprise that from the outset has been concerned with social practice and theory. But, as guest-editor, I have to leave judgment to the readers, as to whether the articles I selected for this collection meet their expectations in this respect. 


\section{Conflicts of Interest}

The author declares no conflict of interest.

\section{References}

1. Social Research: An International Quarterly 2015, 82 .

2. Katzenelson, I. Dark reason: Reflection on the early years of Social Research. Soc. Res. 2015, 82, xxix-xli.

3. Johnson, A. Foreword. Soc. Res. 2015, 82, 3-5. Originally published in Social Research: An International Quarterly of Political and Social Science 1934, 1, 1-2.

4. Kant, I. The Critique of Judgment (Translated with introduction and notes by J.H. Bernard). The University of Adelaide: Adelaide, Australia, 2014 [1790]. Available online: https://ebooks.adelaide.edu.au/k/kant/immanuel/k16ju/ (accessed on 30 September 2015).

5. Wagner, A. What management professionals can learn from Immanuel Kant about purposiveness, critical thinking and design. In Performance Management in Nonprofit-Organisationen; Gmür, M., Schauer R., Theuvsen L, Eds.; Haupt: Bern, Switzerland; Stuttgart, Germany; Wien, Austria, 2013; pp. 238-248.

6. Schön, D.A. The Reflective Practitioner: How Professionals Think in Action; Basic Books: New York, NY, USA, 1983.

7. Harris, M. The Place of Self and Reflexivity in Third Sector Scholarship: An Exploration. Available online: http://nvs.sagepub.com/content/30/4/747 (accessed on 18 August 2015).

8. Rural Electric Magazine, 1 December 2014. Available online: http://remagazine.coop/state-ofchange-2/ (accessed on 25 August 2015).

9. Wagner, A. Good governance: A radical and normative approach to nonprofit management. Voluntas 2014, 25, 797-817.

10. Goshal, S. Bad management theories are destroying good management practices. AMLE 2005, 4, $75-91$.

11. Kant, I. On the common saying: This may be true in theory, but it does not hold in practice. In Immanuel Kant. 'Toward Perpetual Peace' and Other Writings on Politics, Peace, and History; Kleingeld, P.; Yale University Press: New Haven, CT, USA, 2006.

(C) 2015 by the author; licensee MDPI, Basel, Switzerland. This article is an open-access article distributed under the terms and conditions of the Creative Commons Attribution license (http://creativecommons.org/licenses/by/4.0/). 